\title{
$\Lambda$ STUDY OF EIGHT HEATED PLASMA PROTEIN PREPARATIONS
}

\author{
By RICHARD T. SUCHINSKY \\ (From the Department of Health, Education, and Welfare, Public Health Service, National \\ Institutes of Health, Division of Biologics Standards, Bethesda, Md.)
}

(Submitted for publication June 28, 1960; accepted August 17, 1960)

Human plasma has not gained general acceptance as a therapeutic agent because of the risk of hepatitis following its use. A number of physical and chemical treatments have been tried to minimize this risk but the incidence remains about 0.5 per cent for single donor plasma and upwards of 20 per cent for some lots of pooled plasma $(1,2)$. Ultraviolet irradiation, which at one time seemed quite promising, proved incapable of inactivating the hepatitis virus at radiation doses which allowed preservation of the integrity of the plasma proteins. Another physical agent, heat, has demonstrated the ability to reduce markedly, if not completely eliminate, the hepatitis risk in human albumin (3). In this situation an albumin solution containing a stabilizer is heated for 10 hours at $60^{\circ} \mathrm{C}$. This treatment does not modify the protein to an extent which makes it unsuitable for infusion. After more than a decade of wide use, a substantiated case of hepatitis caused by injection of heated human albumin has yet to be reported.

Just as the usefulness and safety of albumin are well recognized, so also are the problems of its high cost, complexity of production, and relatively small yield as compared to plasma. Because of these factors a number of individual investigators and industrial concerns set out to develop a plasma expander which would be as useful therapeutically as albumin, but which would be less expensive and have no greater risk of transmitting hepatitis. Added impetus was given to this program by the need of the Office of Defense Mobilization and the Department of Defense for a safe plasma expander to be manufactured from their outdating stockpile of plasma.

On the basis of the work of Gellis and associates (3) and of Murray (1) on the heating of albumin, most of the investigators involved decided that a major effort should be devoted to developing a plasma derivative which could be heated without adversely affecting the constituent proteins. Murray and co-workers had shown previously (4) that the heating of whole plasma for 4 hours at $60^{\circ} \mathrm{C}$ produced gross changes in the proteins and did not eliminate hepatitis infectivity. It was hoped, however, that the evidence for heat inactivation of virus in albumin could be extrapolated to plasma. The main problem was to develop a procedure which would stabilize the proteins, allowing the plasma derivative to be heated for at least 10 hours at $60^{\circ} \mathrm{C}$ without significant alteration.

The problem was approached in two somewhat different ways. Some of the workers hoped to solve the dilemma by the use of whole plasma to which had been added a chemical stabilizer in order to minimize protein denaturation. Other workers used modifications of the recognized plasma fractionation procedures, intending thereby to eliminate those fractions of plasma which seemed most susceptible to heat denaturation. They hoped that the partially fractionated final product would turn out to be as heat stable and safe as albumin, but less expensive than that preparation.

With the cooperation of the National Research Council, this laboratory had the opportunity of doing simultaneous analyses on these various plasma preparations in an attempt to detect and perhaps evaluate some of the physical and chemical changes which were taking place as a result of the treatments. This report will present comparative data on eight such preparations. When unheated controls were available, they were similarly studied. All materials were also compared with normal unheated citrated plasma.

\section{MATERIALS AND METHODS}

As mentioned previously, the preparations were of two general types: heated whole plasma, and heated, partially fractionated plasma protein solutions. Three of the preparations, designated [1], [2] and [3], were in the first group and five, designated $[\mathrm{A}],[\mathrm{B}],[\mathrm{C}],[\mathrm{D}]$ and [E], were in the second. The methods of production will be described briefly and are summarized in Table I. 
Preparation [1] was made by heating for 10 hours at $60^{\circ} \mathrm{C}$ plasma which had been irradiated with ultraviolet light according to the requirements of the National Institutes of Health (5) and in which standard acid-citratedextrose (6) had been used as an anticoagulant. In preparing [2], serum was filtered, heated at $55^{\circ} \mathrm{C}$ for 10 hours, refiltered, and then lyophilized. Preparation [3] consisted of plasma in 4 per cent citrate as an anticoagulant to which had been added 5 per cent invert sugar. This solution was irradiated with ultraviolet light, filtered, and then heated at $60^{\circ} \mathrm{C}$ for 10 hours. It is noteworthy that in two of these three preparations a sugar was used in an attempt to achieve some stabilization of the proteins. In the other, no stabilizer was used, all precipitated protein being removed after heating.

[A] was prepared by the method of Hink, Hidalgo, Seeberg and Johnson (7). This consisted essentially of fractionating plasma by method 6 of Cohn and co-workers (8) with precipitation of fractions I, II + III, and IV-1. The supernatant IV-1 was precipitated with cold ethanol and the precipitate dried. The precipitate was dissolved in a solution of water, $0.112 \mathrm{M}$ sodium chloride, 0.004 $\mathrm{M}$ sodium acetyltryptophanate, and $0.004 \mathrm{M}$ sodium caprylate (9), and heated for 2 hours at $60^{\circ} \mathrm{C}$, filtered into final containers and then heated at $60^{\circ} \mathrm{C}$ for 10 hours.

Preparation [B] was made by the method of Mulford, Mealey and Welton (10), in which, following a method 6 fractionation through the precipitation of fraction II + III, the supernatant II + III was filtered, dried, reconstituted to 5 per cent in a solution containing $0.008 \mathrm{M}$ sodium acetyltryptophanate and heated at $60^{\circ} \mathrm{C}$ for 10 hours. Preparation [C] represents a modification of this same method in which fractions IV and $\mathrm{V}$ are alcohol precipitated from supernatant II + III with 40 per cent ethanol at $\mathrm{pH} 4.8$, dried, redissolved in a solution containing $0.008 \mathrm{M}$ sodium acetyltryptophanate and heated at $60^{\circ} \mathrm{C}$ for 10 hours.

For the preparation of [D], plasma was first precipitated with 45 per cent saturated ammonium sulfate. The supernatant was treated with a mixture of fatty acids, filtered, and then precipitated with 70 per cent saturated ammonium sulfate. The precipitate was redissolved in saline, $0.04 \mathrm{M}$ sodium caprylate added, and the solution heated at $60^{\circ} \mathrm{C}$ for 10 hours (11). The method of Surgenor and co-workers (12) was used for preparing [E]. This utilized a zinc precipitation technique to remove fibrinogen, $\gamma$-globulin, and some $\beta$-lipoproteins. Zinc was removed from the supernatant by an ion exchange resin, following which the solution was heated at $60^{\circ} \mathrm{C}$ for 10 hours in the presence of sodium caprylate. This material is frequently called "stable plasma protein solution."

Our purpose in carrying out this study was to provide a preliminary evaluation of these products that would help in determining which ones, if any, would merit more detailed, intensive investigation. With this in mind, the following procedures were included in this preliminary screening: gross examination, testing for sterility and pyrogen according to the requirements of the National
Institutes of Health (13), protein concentration by microKjeldahl, nonprotein nitrogen, sodium, potassium, thermal stability, electrophoresis, and ultracentrifugation.

Thermal stability was evaluated by the method described in Reference 13, using an Aminco light-scattering microphotometer. Incubation conditions of $50^{\circ} \mathrm{C}$ for 12 days, $57^{\circ} \mathrm{C}$ for 50 hours, and $-20^{\circ} \mathrm{C}$ for 24 hours for separate samples were utilized. Electrophoresis was performed by the moving boundary method in an AmincoStern apparatus, using barbital buffer at $\mathrm{pH} 8.6$ and 0.1 ionic strength. Mobilities were determined in the usual manner, and relative proportions by the method of completion of the curves and planimetry. Ultracentrifugation was performed on a Spinco model $\mathrm{E}$ ultracentrifuge using the sedimentation velocity technique on the protein solution dialyzed against phosphate buffered saline at $\mathrm{pH}$ 7.2, 0.154 ionic strength. Sedimentation coefficients and relative proportions were both computed. Sodium and potassium determinations were made by flame photometry on a Baird flame photometer.

\section{RESULTS AND DISCUSSION}

The requirements of a plasma expander to be held in a stockpile would seem to be threefold: 1) the material must be safe for infusion in large amounts and at frequent intervals; 2) it must be able to withstand storage and shipment under a considerable range of temperature without undergoing significant changes in the constituents; and 3 ) it must provide the therapeutic effect desired, namely, blood volume expansion. The investigation described herein is an attempt to provide a preliminary indication of the ability of these preparations to fulfill the first two demands. The third is best evaluated by actual clinical trial and thus merits investigation only after the safety and stability of the material are proved.

The sterility tests failed to demonstrate bacterial contamination in any of the preparations. In none of the preparations was the pyrogen reaction greater than that usually considered acceptable.

Simple inspection revealed interesting information on several preparations. A tabulation of the gross appearance of the various materials is shown in Table I. In preparation [3] a progressively increasing reddish-brown color was noted. A much less marked darkening was also noted in preparation [1].

The contrast between preparations [B] and [C] is also pertinent. When received, [B] was found to have a white sediment at the bottom of the container. No such sediment was present in preparation [C]. Information received from the manu- 
TABLE I

Methods of preparation and gross appearance

\begin{tabular}{|c|c|}
\hline Whole plasma products & Fractionated plasma products \\
\hline $\begin{array}{l}\text { [1] Acid-citrate-dextrose plasma, ultraviolet } \\
\text { treatment, heat } 10 \text { hours at } 60^{\circ} \mathrm{C} \\
\text { Heated-yellow, slightly opalescent solution } \\
\text { Unheated-yellow, slightly opalescent } \\
\text { solution }\end{array}$ & $\begin{array}{l}\text { [A] Supernatant IV-1, precipitate with ethanol, } \\
\text { redissolve precipitate in solution containing } \\
\text { stabilizer, heat } 2 \text { hours at } 60^{\circ} \mathrm{C} \text {, filter, heat } \\
10 \text { hours at } 60^{\circ} \mathrm{C} \\
\text { Heated-pale yellow, clear solution } \\
\text { Unheated-pale yellow, clear solution }\end{array}$ \\
\hline $\begin{array}{l}\text { [2] Serum, heat } 10 \text { hours at } 55^{\circ} \mathrm{C} \text {, filter } \\
\text { Heated-yellow, clear solution } \\
\text { Unheated-none available }\end{array}$ & $\begin{array}{l}\text { [B] Supernatant II }+ \text { III, add stabilizer, heat } 10 \\
\text { hours at } 60^{\circ} \mathrm{C} \\
\text { Heated-yellow, slightly opalescent solution } \\
\text { with white sediment } \\
\text { Unheated-none available }\end{array}$ \\
\hline \multirow[t]{3}{*}{$\begin{array}{l}\text { [3] } 4 \% \text { Citrate plasma, } 5 \% \text { invert sugar, ultra- } \\
\text { violet treatment, heat } 10 \text { hours at } 60^{\circ} \mathrm{C} \\
\text { Heated-yellow, clear solution, becoming } \\
\text { progressively redder during storage } \\
\text { Unheated-none available }\end{array}$} & $\begin{array}{l}\text { [C] Fractions IV }+\mathrm{V} \text {, add stabilizer, heat } 10 \text { hours } \\
\text { at } 60^{\circ} \mathrm{C} \\
\text { Heated-yellow, clear solution } \\
\text { Unheated-none available }\end{array}$ \\
\hline & $\begin{array}{l}\text { [D] Supernatant of } 45 \%\left(\mathrm{NH}_{4}\right)_{2} \mathrm{SO}_{4} \text { saturation } \\
\text { treated with mixed fatty acids, filtered, pre- } \\
\text { cipitate with } 70 \% \text { saturated }\left(\mathrm{NH}_{4}\right)_{2} \mathrm{SO}_{4} \text {, re- } \\
\text { dissolve and add stabilizer, heat } 10 \text { hours at } \\
60{ }^{\circ} \mathrm{C} \\
\text { Heated-amber, clear solution } \\
\text { Unheated plasma-slightly cloudy, yellow } \\
\text { brown solution }\end{array}$ \\
\hline & $\begin{array}{l}\text { [E] Zinc precipitation, removal of zinc from super- } \\
\text { natant, add stabilizer, heat } 10 \text { hours at } 60^{\circ} \mathrm{C} \\
\text { Heated-clear, yellow solution which became } \\
\text { progressively more cloudy during storage at } \\
5^{\circ} \mathrm{C} \\
\text { Unheated-none available }\end{array}$ \\
\hline
\end{tabular}

facturer indicated that both preparations were clear and without sediment before shipping. To check this, another sample of [B], known to be without sediment just before shipment, was sent to us and found to have a significant amount of white sediment on receipt. It was evident that rather slight changes in the method of preparation could be responsible for a significant difference in the ability of a preparation to undergo shipment without alteration. The difference between [B] and $[\mathrm{C}]$ is further emphasized by examination of the ultracentrifugal patterns of the two preparations (Table V and Figure 4). Rapidly sedimenting components are present in both [B] and [C]. The rapid component in [C], however, has a sedimentation coefficient significantly lower than the comparable one in [B], and represents less of the total protein present. Subsequent pictures in each of the runs seem to indicate that the fast moving component consists of a great number of smaller components, each with a slightly different sedimentation coefficient.
The protein, nonprotein nitrogen, sodium, and potassium values are listed in Table II. All of the preparations, except [D], had protein concentrations approximately equal to, or exceeding that of plasma. Preparation [D], which had a concentration slightly lower than the others, could easily be prepared in a manner that would raise its concentration to a level comparable to that of the others.

TABLE II

Results of protein, nonprotein nitrogen, $\mathrm{pH}, \mathrm{Na}^{+}$and $\mathrm{K}^{+}$ determinations

\begin{tabular}{|c|c|c|c|c|c|c|}
\hline \multicolumn{2}{|r|}{ Product } & Protein & NPN & $\mathrm{pH}$ & $\mathrm{Na}+$ & $\mathbf{K}+$ \\
\hline $\begin{array}{l}{[1]} \\
{[1]} \\
{[2]} \\
{[2]} \\
{[3]}\end{array}$ & $\begin{array}{l}\text { Heated } \\
\text { Unheated } \\
\text { Heated } \\
\text { Unheated } \\
\text { Heated }\end{array}$ & $\begin{array}{c}\mathrm{g} / 100 \mathrm{ml} \\
5.11 \\
5.02 \\
6.92 \\
7.00 \\
5.28\end{array}$ & $\begin{array}{c}m g / 100 m l \\
20 \\
26 \\
17 \\
18 \\
17\end{array}$ & $\begin{array}{l}7.82 \\
8.08 \\
8.05 \\
7.96 \\
7.61\end{array}$ & $\begin{array}{l}m E q / L \\
192 \\
192 \\
135 \\
134 \\
186\end{array}$ & $\begin{array}{c}m E q / L \\
0.2 \\
0.3 \\
5.1 \\
7.0 \\
4.0\end{array}$ \\
\hline $\begin{array}{l}{[\mathrm{A}]} \\
{[\mathrm{A}]} \\
{[\mathrm{B}]} \\
{[\mathrm{C}]} \\
{[\mathrm{D}]} \\
{[\mathrm{D}]}\end{array}$ & $\begin{array}{l}\text { Heated } \\
\text { Unheated } \\
\text { Heated } \\
\text { Heated } \\
\text { Heated } \\
\text { Unheated } \\
\text { plasma }\end{array}$ & $\begin{array}{l}4.72 \\
4.87 \\
4.89 \\
4.57 \\
3.60 \\
6.87\end{array}$ & $\begin{array}{l}20 \\
20 \\
41 \\
21 \\
12 \\
42\end{array}$ & $\begin{array}{l}7.02 \\
6.93 \\
6.64 \\
7.90 \\
6.41 \\
7.44\end{array}$ & $\begin{array}{l}134 \\
134 \\
235+ \\
235+ \\
143 \\
130\end{array}$ & $\begin{array}{c}1.4 \\
1.4 \\
18.9 \\
\text { Trace } \\
\text { Trace } \\
6.7\end{array}$ \\
\hline [E] & Heated & 5.25 & 52 & 7.78 & 234 & Trace \\
\hline
\end{tabular}


TABLE III

Thermal stability estimated nephelometrically *

\begin{tabular}{|c|c|c|c|c|c|c|c|c|c|}
\hline & \multicolumn{3}{|c|}{$50^{\circ} \mathrm{C}$} & \multicolumn{3}{|c|}{$57^{\circ} \mathrm{C}$} & \multicolumn{3}{|c|}{$-20^{\circ} \mathrm{C}$} \\
\hline & Initial & After 12 days & Change & Initial & After $50 \mathrm{hrs}$ & Change & Initial & After $24 \mathrm{hrs}$ & Change \\
\hline [1] Heated & 192 & 314 & 122 & 191 & 341 & 150 & 272 & Too turbid & $?$ \\
\hline $\begin{array}{l}{[1] \text { Unheated }} \\
{[2] \text { Heated }}\end{array}$ & $\begin{array}{l}144 \\
137\end{array}$ & $\begin{array}{l}276 \\
384\end{array}$ & $\begin{array}{l}132 \\
247\end{array}$ & $\begin{array}{l}136 \\
115\end{array}$ & $\begin{array}{c}285 \\
\text { Soft gel }\end{array}$ & $\begin{array}{c}149 \\
?\end{array}$ & $\begin{array}{l}116 \\
197\end{array}$ & $\begin{array}{l}169 \\
\text { Too turbid }\end{array}$ & $\begin{array}{c}53 \\
?\end{array}$ \\
\hline $\begin{array}{l}{[2] \text { Unheated }} \\
\text { [3] Heated }\end{array}$ & $\begin{array}{l}85 \\
84\end{array}$ & $\begin{array}{l}345 \\
100\end{array}$ & $\begin{array}{r}260 \\
16\end{array}$ & $\begin{array}{l}82 \\
77\end{array}$ & $\begin{array}{c}\text { Soft gel } \\
124\end{array}$ & $?_{47}$ & 81 & 163 & 82 \\
\hline $\begin{array}{l}{[A] \text { Heated }} \\
{[B] \text { Heated }} \\
\text { [C] Heated } \\
\text { [D] Heated } \\
\text { [E] Heated }\end{array}$ & $\begin{array}{r}22 \\
130 \\
106 \\
6 \\
145\end{array}$ & $\begin{array}{c}25 \\
108 \\
100 \\
10 \\
\text { Too turbid } \\
\text { to read }\end{array}$ & $\begin{array}{r}3 \\
-22 \\
-6 \\
4\end{array}$ & $\begin{array}{r}20 \\
141 \\
92 \\
6 \\
134\end{array}$ & $\begin{array}{c}21 \\
103 \\
107 \\
8 \\
\text { Too turbid } \\
\text { to read }\end{array}$ & $\begin{array}{r}1 \\
-38 \\
15 \\
2\end{array}$ & $\begin{array}{l}23 \\
172 \\
125 \\
9 \\
\text { Cloudy after } \\
2 \text { wks in re- } \\
\text { frigerator at } \\
3^{\circ} \mathrm{C} \text { (too } \\
\text { turbid to } \\
\text { read) }\end{array}$ & $\begin{array}{c}53 \\
172 \\
179 \\
13 \\
\text { Striking } \\
\text { increase } \\
\text { in } \\
\text { turbidity }\end{array}$ & $\begin{array}{r}20 \\
0 \\
54 \\
4 \\
?\end{array}$ \\
\hline
\end{tabular}

* Units are arbitrary "nephelometric units" (13).

Preparations [B] and [E] had nonprotein nitrogen values which were appreciably higher than those found in any of the other materials. There seems to be some correlation in samples [B], [C], and [E] between lack of thermal stability, or lack of stability on shipment, and higher nonprotein nitrogen values. It is of interest that although [B] and $[\mathrm{C}]$ had the same amounts of sodium acetyl-

TABLE IV

Moving boundary electrophoresis

\begin{tabular}{|c|c|c|c|c|c|c|c|}
\hline Material & $\underset{\text { nent }}{\text { Compo- }}$ & Mobility* & $\begin{array}{c}\text { Relative } \\
\text { proportion }\end{array}$ & Material & $\begin{array}{c}\text { Compo- } \\
\text { nent }\end{array}$ & Mobility* & $\begin{array}{c}\text { Relative } \\
\text { proportion }\end{array}$ \\
\hline \multirow{5}{*}{ [1] Heated } & & & $\%$ & \multirow{3}{*}{ [A] Heated } & & & $\%$ \\
\hline & a & -6.7 & 49.3 & & a & -6.8 & 86.6 \\
\hline & $\mathrm{b}$ & -4.6 & 46.5 & & $\mathrm{~b}$ & -5.2 & 11.3 \\
\hline & c & -3.3 & 0.9 & \multirow{3}{*}{ [A] Unheated } & c & -3.5 & 2.0 \\
\hline & d & -1.6 & 3.3 & & a & -6.5 & 85.2 \\
\hline \multirow{6}{*}{ [1] Unheated } & $\mathrm{a}$ & -6.6 & 62.5 & & $\mathrm{a}$ & -4.4 & 5.3 \\
\hline & $\mathrm{b}$ & -5.6 & 8.8 & & $\mathrm{c}$ & -3.4 & 9.2 \\
\hline & c & -4.3 & 12.0 & \multirow{4}{*}{ [B] Heated } & & & \\
\hline & d & -3.2 & 6.3 & & a & -6.4 & 85.2 \\
\hline & $\mathrm{e}$ & -1.3 & 10.4 & & $\begin{array}{l}a \\
b\end{array}$ & -4.8 & 13.6 \\
\hline & & & & & c & -3.2 & 1.2 \\
\hline \multirow[t]{4}{*}{ [2] Heated } & $\mathrm{a}$ & -6.4 & 50.0 & \multirow{5}{*}{ [C] Heated } & & & \\
\hline & b & -5.4 & 2.9 & & a & -6.8 & 81.4 \\
\hline & c & -4.0 & 26.6 & & $\mathrm{~b}$ & -5.2 & 17.2 \\
\hline & d & -3.2 & 10.4 & & $\mathrm{c}$ & -3.2 & 1.3 \\
\hline \multirow{6}{*}{ [2] Unheated } & e & $\begin{array}{l}-1.2 \\
-62\end{array}$ & $\begin{array}{l}10.2 \\
58.1\end{array}$ & & & & 005 \\
\hline & b & $\begin{array}{l}-0.2 \\
-5.3\end{array}$ & $\begin{array}{r}30.1 \\
4.7\end{array}$ & \multirow{2}{*}{ [D] Heated } & $\begin{array}{l}\mathrm{a} \\
\mathrm{b}\end{array}$ & $\begin{array}{l}-6.1 \\
-4.8\end{array}$ & $\begin{array}{r}88.5 \\
6.8\end{array}$ \\
\hline & c & -3.9 & 12.0 & & c & -3.0 & 4.7 \\
\hline & d & -2.8 & 13.0 & \multirow{5}{*}{$\begin{array}{l}\text { [D }] \text { Unheated } \\
\text { plasma }\end{array}$} & a & -5.7 & 60.7 \\
\hline & e & -1.3 & 12.3 & & $\mathrm{~b}$ & -4.1 & 9.0 \\
\hline & & & & & $c$ & -3.4 & 8.7 \\
\hline \multirow[t]{5}{*}{ [3] Heated } & a & $\begin{array}{l}-6.4 \\
-4.6\end{array}$ & $\begin{array}{l}49.3 \\
47.9\end{array}$ & & $\mathrm{~d}$ & $\begin{array}{l}-2.4 \\
-17\end{array}$ & 8.4 \\
\hline & c & -1.7 & 2.8 & & $\mathrm{f}$ & -0.6 & 10.1 \\
\hline & & & & \multirow[t]{3}{*}{ [E] Heated } & a & -6.3 & 79.0 \\
\hline & & & & & $\mathrm{b}$ & -4.5 & 18.2 \\
\hline & & & & & c & -3.0 & 2.8 \\
\hline
\end{tabular}

* Mobility is shown in $\mathrm{cm}^{2} /$ volt $/ \mathrm{sec} \times 10^{-5}$. 
[1] HEATED

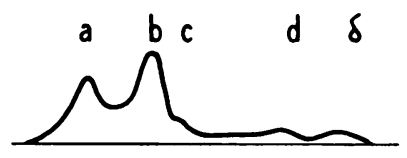

[1] UNHEATED

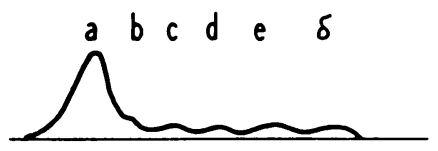

[2] HEATED

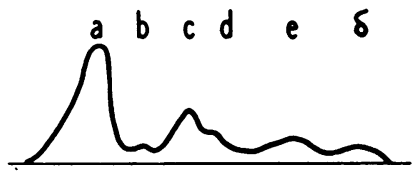

[2] UNHEATED

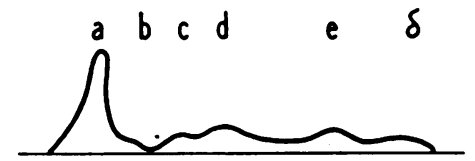

[3] HEATED

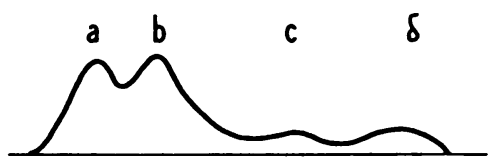

Fig. 1. Electrophoretic patterns of whole plasma samples. Direction of migration is from right to left.

tryptophanate added, preparation [C] had a nonprotein nitrogen value only half that of [B]. Preparation [E] had no added nitrogen-containing stabilizer. The significance, if any, of this finding is not clear, but may be an indication of the breaking off of small peptide groups as a result of heating and/or storage of plasma proteins under certain conditions.
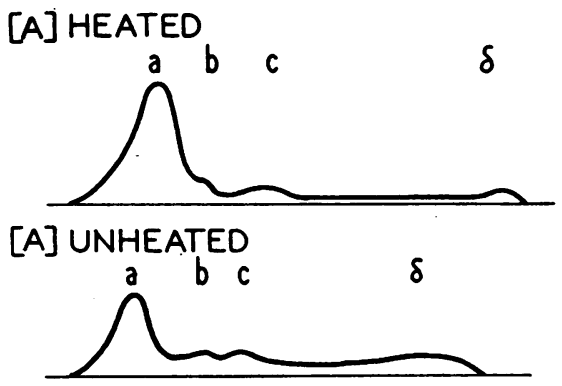

[B] HEATED
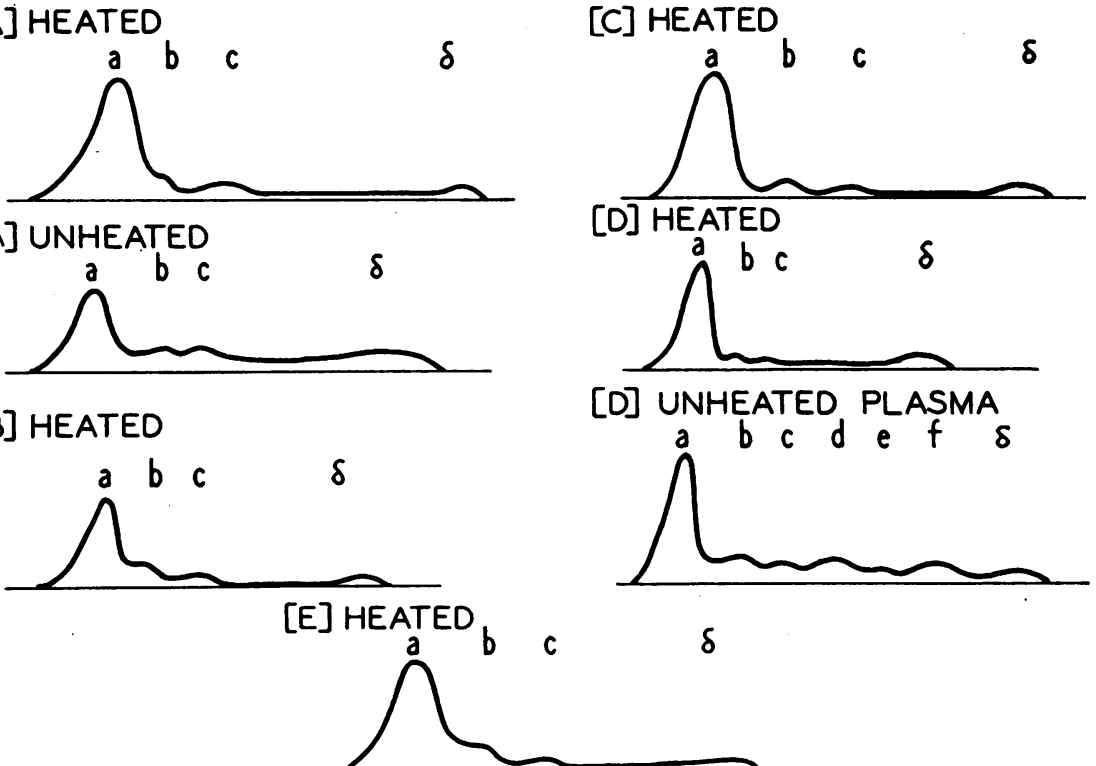

$\delta$

Fig. 2. Electrophoretic patterns of fractionated samples. Direction of migration is from right to left. 
TABLE V

Ultracentrifugal analyses

\begin{tabular}{|c|c|c|c|c|c|c|c|}
\hline Material & $\begin{array}{c}\text { Compo- } \\
\text { nent }\end{array}$ & $\mathrm{s}^{\mathrm{o}} 20$, & $\begin{array}{c}\text { Relative } \\
\text { proportion }\end{array}$ & Material & $\begin{array}{c}\text { Compo- } \\
\text { nent }\end{array}$ & $\mathrm{s}^{\circ} 20, \mathrm{w}$ & $\begin{array}{c}\text { Relative } \\
\text { proportion }\end{array}$ \\
\hline \multirow{4}{*}{ [1] Heated } & \multirow{4}{*}{$\begin{array}{l}\text { I } \\
\text { II } \\
\text { III }\end{array}$} & \multirow{4}{*}{$\begin{array}{r}21.0 \\
6.6 \\
4.4\end{array}$} & \multirow{4}{*}{$\begin{array}{r}\% \\
12 \\
6 \\
82\end{array}$} & \multirow{3}{*}{ [A] Heated } & \multirow{3}{*}{$\begin{array}{l}\text { I } \\
\text { II }\end{array}$} & \multirow{3}{*}{$\begin{array}{r}14.0 \\
3.9\end{array}$} & $\%$ \\
\hline & & & & & & & 4 \\
\hline & & & & & & & 96 \\
\hline & & & & [A] Unheated & I & 3.9 & 100 \\
\hline \multirow[t]{2}{*}{ [1] Unheated } & I & 17.5 & $\begin{array}{r}7 \\
15\end{array}$ & \multirow{2}{*}{ [B] Heated } & & & \\
\hline & $\begin{array}{l}\text { II } \\
\text { III }\end{array}$ & $\begin{array}{l}6.5 \\
4.3\end{array}$ & $\begin{array}{l}15 \\
78\end{array}$ & & II & $\begin{array}{r}21.0 \\
4.0\end{array}$ & 92 \\
\hline \multirow[t]{2}{*}{ [2] Heated } & I & 17.6 & 3 & \multirow[t]{2}{*}{ [C] Heated } & I & 17.0 & 6 \\
\hline & III & $\begin{array}{l}0.8 \\
4.1\end{array}$ & $\begin{array}{l}19 \\
78\end{array}$ & & & & \\
\hline \multirow{6}{*}{ [3] Heated } & I & 230 & 13 & \multirow{2}{*}[\mathrm{D}]{ Heated } & I & $\begin{array}{r}24.0 \\
3.8\end{array}$ & $\begin{array}{r}2 \\
98\end{array}$ \\
\hline & II & 6.7 & 11 & & & & \\
\hline & III & 4.3 & 76 & \multirow{2}{*}{$\begin{array}{l}\text { [D] Unheated } \\
\text { plasma }\end{array}$} & I & 16.5 & 4 \\
\hline & & & & & $\begin{array}{l}\text { II } \\
\text { III }\end{array}$ & $\begin{array}{l}6.2 \\
4.0\end{array}$ & $\begin{array}{l}19 \\
77\end{array}$ \\
\hline & & & & \multirow{2}{*}{ [E] Heated } & I & 20.0 & 6 \\
\hline & & & & & II & 4.0 & 94 \\
\hline
\end{tabular}

Table III indicates the relative changes in turbidity after exposure to temperatures of $50^{\circ} \mathrm{C}$ for 12 days, $57^{\circ} \mathrm{C}$ for 50 hours and $-20^{\circ} \mathrm{C}$ for 24 hours. All of the heated whole plasma preparations demonstrated generally poor thermal sta- bility at the various temperatures. Also noteworthy is the poor stability in the cold of preparation [E], a situation which could be inferred from the gross observation. Of the fractionated materials, this preparation seemed the least stable

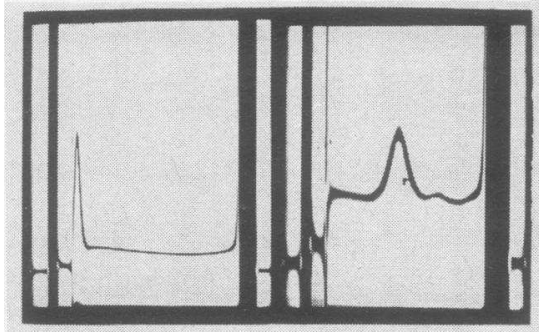

[1] Heated

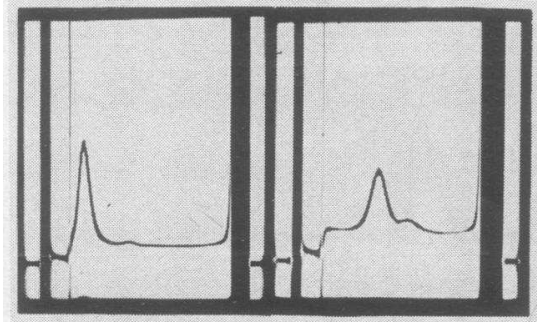

(1) Unheated

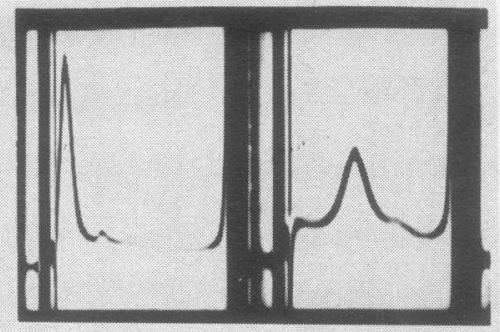

[2] Heated

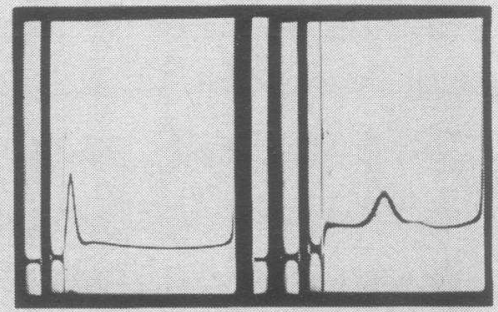

[3] Heated

Fig. 3. Ultracentrifugal patterns of whole plasma samples. Times of pictures after attainment of full speed are as follows: [1] heated, 231 and 5,031 seconds; [1] unheated, 853 and 3,973 seconds; [2] heated (at 44,770 rpm), 1,326 and 9,006 seconds; [3] heated, 272 and 4,112 seconds. 
at all temperatures. The decrease in the nephelometric reading of [B] after heating is possibly due to enlarging of small aggregates with subsequent sedimentation.

The low temperature instability of the whole plasma preparations is consistent with, and probably a result of lipoprotein denaturation at low temperatures as described by Oncley, Gurd and Melin (14). The low temperature instability noted in $[\mathrm{E}]$ is not as readily understandable, but may also be a reflection of the presence of significant amounts of lipoprotein.

The results of the electrophoretic analyses are given in Table IV, the patterns in Figures 1 and 2.
These demonstrate marked changes in the heated whole plasmas containing sugar, i.e., [1] and [3]. These changes consist primarily of decreases in proteins moving with mobilities of albumin and $\beta$ - and $\gamma$-globulins, and marked increases in proteins having mobilities comparable to those of $\alpha_{2}{ }^{-}$ globulins. This is consistent with the findings of Miyamoto, Sakagishi and Sano (15), Ardry (16), and Bozzetti and Prina (17). On electrophoretic examination, preparation [2] seemed relatively less changed than either of the other similar preparations, although there was an increase in the component with the mobility of $\alpha_{2}$-globulin. The fractionated preparation on which an unheated

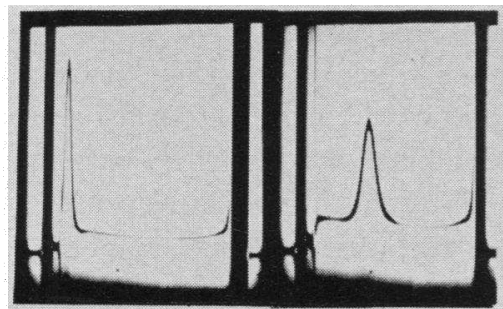

[A] Heated

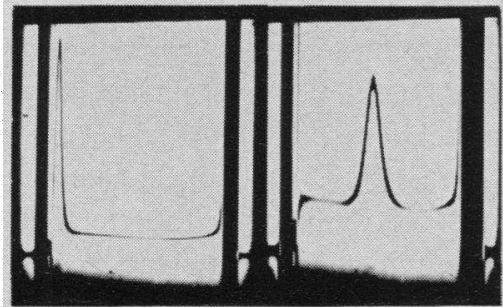

[A] Unheated

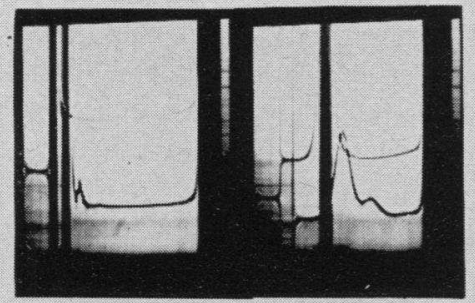

[D] Heated (upper) Unheated plasma (lower)

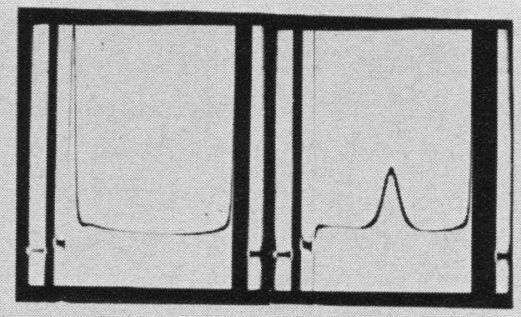

[B] Heated

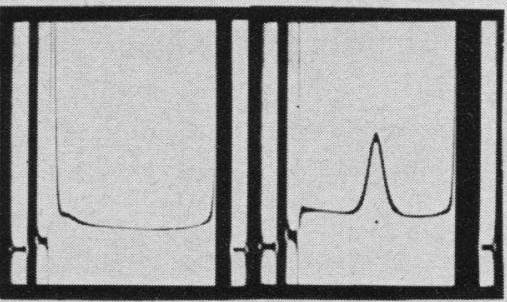

[C] Heated

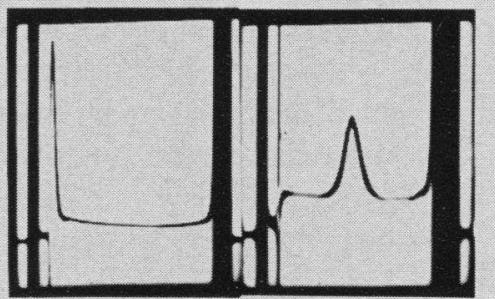

[E] Heated

Fig. 4. Ultracentrifugal patterns of Fractionated samples. Times of pictures after attainment of full speed are as follows: [A] heated, 434 and 4,561 seconds; [A] unheated, 366 and 6,121 seconds; [B] heated, 233 and 5,993 seconds; [C] heated, 169 and 6,167 seconds; [D] heated, 221 and 3,912 seconds ; [D] unheated plasma, 221 and 3,912 seconds; [E] heated, 201 and 5,961 seconds. 
control was available, $\lfloor\Lambda\rfloor$, demonstrated changes of a much less striking nature in its electrophoretic pattern.

These findings on electrophoresis together with the color changes previously noted may be indicative, among other things, of a type of protein degradation characterized by an initial reaction between the protein and reducing sugars. This type of "browning reaction" occurring in systems containing amine groups and reducing sugars is treated exhaustively by Hodge (18). This reaction may be of great significance in influencing the stability of protein solutions. Suggestive evidence is indicated in the electrophoretic patterns of Figure 1, in which the changes in preparation [2], a material with no added reducing sugar, are significantly less marked than those in preparations [1] and [3], both of which have added reducing sugars. The lower temperature of heating of preparation [2] may also be significant in lessening the changes detected by electrophoresis. A number of unpublished observations in our laboratory, however, tend to support the idea that the addition of reducing sugars to certain protein systems may potentiate protein denaturation. This problem is currently under investigation by our group in an attempt to determine its significance.

The results of the ultracentrifugal analyses are indicated in Table $\mathrm{V}$ and in Figures 3 and 4. Preparations [1], [3], [B] and [E] revealed measurable amounts of very rapidly sedimenting material. All of the other preparations exhibited a relatively rapid sedimenting component having an $\mathrm{s}^{\circ}{ }_{20, \mathrm{w}}$ greater than 10 and less than 18 . It is noteworthy that in preparation [A] no rapidly sedimenting component is present in the unheated control. It would be unusual for significant amounts of relatively high molecular weight substance to remain in a preparation after any of the fractionation procedures previously described. One is probably justified, therefore, in assuming that the appearance of significant amounts of rapidly sedimenting component in the fractionated preparations is a result of the formation of high molecular weight species during heating. The presence of relatively large amounts of rapidly sedimenting component in the whole plasma preparations may similarly be attributed to heating or storage, since these components are not usually seen in more than trace amounts in either serum or plasma which has not been concentrated prior to centrifugation.

\section{CONCLUSIONS}

The purpose of this study was to attempt to obtain a preliminary indication of the possible potential clinical usefulness of the various heated plasma preparations. It was hoped that on the basis of a few selected physical and chemical tests, some assumptions could be made regarding the safety of the products. Certainly, the final judgment regarding safety can depend only on appropriate intensive immunological, toxicological, and clinical studies. However, an attempt was made to determine which preparations seemed most promising and would merit the intensive studies necessary to establish whether they were safe and potent enough for routine clinical use.

On the basis of these tests, we felt that a certain number of conclusions could be drawn which would allow the preparations to be graded as to their relative promise. Certain products could be put into the doubtful category because of their inability to withstand shipment and/or temperature extremes without giving indications of protein change. These would include at least preparations $[\mathrm{B}]$ and $[\mathrm{E}]$, and most likely preparations [1], [2] and [3]. Some products were in doubt because of findings in the electrophoretic and/or ultracentrifugal analyses which seemed to indicate major changes in the proteins. We were primarily concerned with the appearance of the rapidly sedimenting component which was present in relatively large amounts in certain of these products. Because of the experience with dextran, which seemed to indicate an adverse effect of very high molecular weight colloidal substances on the clotting system (19), and because of the possibility of reticuloendothelial blockade by high molecular weight abnormal proteins with an adverse effect on the reaction of this system to the shock situation $(20,21)$, we believed caution was necessary in any in vivo preparations testing of [1], [2], $[3],[\mathrm{B}]$ and $[\mathrm{E}]$, the same preparations put in doubt by the stability studies.

Three of the preparations, [A], [C] and [D], all fractionated materials, seemed the most prom- 
ising on the basis of these preliminary physical and chemical determinations. These three preparations demonstrated relatively good stability characteristics, showed less marked changes on electrophoresis and ultracentrifugation than the others, and contained a high proportion of albumin (greater than 80 per cent) which brought them close in character to a material which has already proved clinically safe and effective, normal serum albumin (human).

The clinical significance of the changes noted in any of the preparations is unknown at this time.

\section{SUM MARY}

Eight heated plasma preparations were compared by a number of physical and chemical techniques. These tests demonstrated better stability characteristics and resistance to molecular change in those preparations which had undergone a partial fractionation procedure prior to heating. Three preparations produced by different fractionation methods were deemed to be the most promising as possible plasma expanders for human use and meriting further study both in vivo and in vitro. These were, respectively, a precipitate from supernate IV-1 of Cohn's fractionation method 6, fractions IV $+\mathrm{V}$ from Cohn's method 6 , and a preparation from the supernate of plasma 45 per cent saturated with ammonium sulfate.

\section{ACKNOWLEDGMENTS}

The author wishes to acknowledge the assistance of Dr. J. T. Tripp of this laboratory, Dr. Margaret Sloan and her associates at the National Academy of SciencesNational Research Council, and the firms and individuals involved in the preparation of these samples for their cooperation in providing the materials studied. The technical assistance of the staff of this laboratory is also gratefully acknowledged.

\section{REFERENCES}

1. Murray, R. Viral hepatitis. Bull. N. Y. Acad. Med. 1955, 31, 341.

2. Lehane, D., Kwantes, C. M. S., Upward, M. G., and Thompson, D. R. Homologous serum jaundice. Brit. med. J. 1949, II, 572.

3. Gellis, S. S., Neefe, J. R., Stokes, J., Jr., Strong, L. E., Janeway, C. A., and Scatchard, G. Chemical, clinical, and immunological studies on the products of human plasma fractionation. XXXVI. Inac- tivation of the virus of homologous serum hepatitis in solutions of normal human serum albumin by means of heat. J. clin. Invest. 1948, 27, 239.

4. Murray, R., Diefenback, W. C. L., Geller, H., Leone, N. C., and Ratner, F. The problem of reducing the danger of serum hepatitis from blood and blood products. N. Y. St. J. Med. 1955, 55, 1145.

5. Minimum Requirements: Ultraviolet Irradiation for the Sterilization of Biologic Products. U. S. Public Health Service, 2nd revision, 1953.

6. Additional Standards: Whole Blood (Human). Public Health Service Regulations, part 73, section 73.302 (d), revised, 1958.

7. Hink, J. H., Jr., Hidalgo, J., Seeberg, V. P., and Johnson, F. F. Preparation and properties of a heat-treated human plasma protein fraction. Vox Sang. (Basel) 1957, 2, 174.

8. Cohn, E. J., Strong, L. E., Hughes, W. L., Jr., Mulford, D. J., Ashworth, J. N., Melin, M., and Taylor, H. L. Preparation and properties of serum and plasma proteins. IV. A system for the separation into fractions of the protein and lipoprotein components of biological tissues and fluids. $\mathrm{J}$. Amer. chem. Soc. 1946, 68, 459.

9. Ballou, G. A., Boyer, P. D., Luck, J. M., and Lum, F. G. The heat coagulation of human serum albumin. J. biol. Chem. 1944, 153, 589.

10. Mulford, D. J., Mealey, E. H., and Welton, L. D. Preparation of a stable human plasma protein solution. J. clin. Invest. 1955, 34, 983.

11. Auerswald, W., Doleschel, W., and Szegvari, G. Physikochemischer und immunologischer Vergleich stabilisierter gelöster humaner Plasmaproteinfraktionen (PPF) vor und nach Hitzeinaktivierung. Anaesthesist 1959, 8, 106.

12. Surgenor, D. M., Pennell, R. B., Alameri, E., Batchelor, W. H., Brown, R. K., Hunter, M. J., and Mannick, V. Preparation and properties of serum and plasma proteins, XXXV. A system of protein fractionation using zinc complexes. Vox Sang. (Basel) 1960, 5, 272.

13. Minimum Requirements: Normal Serum Albumin (Human). U. S. Public Health Service, 8th revision, 1953.

14. Oncley, J. L., Gurd, F. R. N., and Melin, M. Preparation and properties of serum and plasma proteins. XXV. Composition and properties of human serum $\beta$-lipoprotein. J. Amer. chem. Soc. 1950, 72, 458.

15. Miyamoto, S., Sakagishi, Y., and Sano, R. On the physico-chemical changes of serum protein under mild heat-treatment. (3) On the electrophoretical changes of the protein fractions in heated serum. Bull. Tokyo med. dent. Univ. 1957, 4, 55.

16. Ardry, R. Recherches électrophorétiques sur le sérum humain chauffé. I. Etude du sérum normal. Bull. Soc. Chim. biol. (Paris) 1951, 33, 236.

17. Bozzetti, E., and Prina, C. Ricerche elettroforetiche sulla denaturazione del siero. 1) Sulla denatura- 
zionc termica del siero umano normale. Boll. Soc. ital. Biol. sper. 1955, 31, 953.

18. Hodge, J. E. Dehydrated foods, chemistry of browning reactions in model systems. J. Agric. Food Chem. 1953, 1, 928.

19. Jacobaeus, U. Studies on the effect of dextran on the coagulation of blood. Acta med. scand. 1957, 157, suppl. 322.

20. Benacerraf, B., Biozzi, G., Halpern, B. N., Stiffel, C., and Mouton, D. Phagocytosis of heat-denatured human serum albumin labelled with ${ }^{131} \mathrm{I}$ and its use as a means of investigating liver blood flow. Brit. J. exp. Path. 1957, 38, 35.

21. Zweifach, B. W., Benacerraf, B., and Thomas, L. The relationship between the vascular manifestations of shock produced by endotoxin, trauma, and hemorrhage. II. The possible role of the reticuloendothelial system in the resistance to each type of shock. J. exp. Med. 1957, 106, 403. 